\title{
Communication Regarding Sustainability: Conceptual Perspectives and Exploration of Societal Subsystems
}

\author{
Jens Newig ${ }^{1}{ }^{*}$, Daniel Schulz ${ }^{1}$, Daniel Fischer ${ }^{1}$, Katharina Hetze ${ }^{1}$, Norman Laws ${ }^{1}$, \\ Gesa Lüdecke $^{1}$ and Marco Rieckmann ${ }^{2}$
}

1 Institute for Sustainability Communication, Leuphana University Lüneburg, Scharnhorststr. 1, Lüneburg 21335, Germany; E-Mails: daniel.schulz@leuphana.de (D.S.); daniel.fischer@uni.leuphana.de (D.F.); hetze@uni.leuphana.de (K.H.); laws@uni.leuphana.de (N.L.); luedecke@uni.leuphana.de (G.L.)

2 Institute for Social Work, Education and Sport Sciences, University of Vechta, Driverstr. 22, Vechta 49377, Germany; E-Mail: marco.rieckmann@uni-vechta.de

* Author to whom correspondence should be addressed; E-Mail: newig@uni.leuphana.de; Tel.: +49-4131-677-1726; Fax: +49-4131-677-2819.

Received: 18 May 2013; in revised form: 28 June 2013 / Accepted: 1 July 2013 /

Published: 9 July 2013

\begin{abstract}
Sustainability issues are typically characterized by high complexity and uncertainty. In light of this, communication plays a crucial role in coping with these challenges. The previous debate on sustainability communication has largely focused on how to communicate sustainability issues to others. Sustainability communication, however, involves more than sender oriented communication to persuade others ("communication of sustainability"); it also embraces processes of dialogue and discourse ("communication about sustainability"). Based on this distinction, we develop a typology of communication modes, including communication for sustainability. Inspired by the notion of functional communication systems, we explore sustainability communication in six societal subsystems, applying the typology of communication modes. Drawing mostly on examples from Germany, we find a shift from "communication of" towards "communication about" sustainability in most subsystems. While communication subsystems have a tendency towards operational closure, a variety of interlinkages exist. We discuss three key areas of "opening up" communication subsystems, leading to transdisciplinarity, societal deliberation and governance, each meeting one of sustainability's core challenges.
\end{abstract}

Keywords: Sustainability communication; typology of communication; communication of. about and for sustainability; transdisciplinarity; deliberation; governance 


\section{Introduction}

Sustainable development, understood as a societal process of exploration, learning and shaping the future [1], necessarily involves communication. As global sustainability issues are characterized by high complexity and uncertainty, effective communication processes between the many actors involved are crucial to develop a mutual understanding of which actions to take [2,3]. While the debate on sustainable development is rich and has reached a matured state, the aspect of communication has only recently attracted increased attention in this field [4]. This new debate draws upon existing scholarship on environmental, risk and science communication [5-7]. Within the broad framework of "sustainability communication" [2], subfields have been emerging such as corporate sustainability communication [8], climate change communication [9,10] or sustainable consumption communication [11]. Research has largely oriented itself along the discourses in such social subsystems. A broader comparative perspective, however, seems to be missing.

This article aims to bring these isolated perspectives together by comparing sustainability-related communication in different societal subsystems as well as to explore interlinkages between them. To this end, we develop a framework for comparison that has two components, a process-centered component and a content-centered one. The first relates to the mode of the communication process, characterizing how communication takes place (Table 1), while the second focuses on the objectives actors might pursue (Table 2). In a first attempt to explore the usefulness of this typology, we then turn to how sustainability communication takes place in different societal subsystems, what interlinkages, but also what barriers of cross-system communication can occur. We then discuss whether sustainability communication is something "unique" or simply communication that happens to deal with sustainability. The article closes by outlining avenues for further research and debate.

Table 1. Communication about sustainability and communication of sustainability in comparison.

\begin{tabular}{clll}
\hline & $\begin{array}{l}\text { Direction/mode of } \\
\text { communication }\end{array}$ & Function & Measures of effectiveness \\
\hline $\begin{array}{c}\text { Communication about } \\
\text { sustainability }(\mathrm{CaS})\end{array}$ & $\begin{array}{l}\text { Deliberative; } \\
\text { horizontal, } \\
\text { many to many }\end{array}$ & $\begin{array}{l}\text { Deliberation; production } \\
\text { of intersubjective/shared } \\
\text { concepts/frames }\end{array}$ & $\begin{array}{l}\text { Discourse oriented: quality } \\
\text { of discourse; compatibility } \\
\text { of concepts to sustainability }\end{array}$ \\
\hline $\begin{array}{c}\text { Communication } \\
\text { of sustainability }(\mathrm{CoS})\end{array}$ & $\begin{array}{l}\text { Transmissive; } \\
\text { sender-receiver, } \\
\text { one to many }\end{array}$ & $\begin{array}{l}\text { Transmission; transfer of } \\
\text { information towards an } \\
\text { objective }\end{array}$ & $\begin{array}{l}\text { Sender oriented: } \\
\text { achievement of sender's } \\
\text { communication objective }\end{array}$ \\
\hline
\end{tabular}

\section{Rationales and Perspectives}

\subsection{Rationales for Sustainability Communication}

Why is communication fundamental for sustainable development? With a procedural understanding of sustainable development, societal discourse is key to providing legitimacy. With a substantive understanding, sustainability is an issue that is complex in three dimensions, each of which poses specific challenges that call for societal communication on their own account [3]: 
(1) Sustainability issues are typically characterized by high levels of complexity and uncertainty. In conjunction with high decision stakes, scholars such as Funtowicz and Ravetz [12] call for new modes of science involving increased communication, dialogue, and the involvement of stakeholders to broaden the information basis, but also to include broader societal values.

(2) Sustainability goals are typically ambivalent, involving conflicts of interests as well as of values. Communication is essential in order to reach a common understanding about societal values on sustainability and concrete goals that need to be pursued.

(3) The capacities to govern sustainable development tend to be highly dispersed among a wealth of societal actors on multiple levels of decision-making, making implementation of measures to achieve those few goals that have been agreed on all the more difficult. Network-like forms of coordination that enable effective arguing, bargaining, and social learning are regarded as conducive to governing sustainable development in the face of distributed action capacity.

Table 2. Typology of communication processes in relation to sustainability with examples.

\begin{tabular}{|c|c|c|c|}
\hline & $\begin{array}{l}\text { Communication } \\
\text { counterproductive to } \\
\text { sustainability }\end{array}$ & $\begin{array}{l}\text { Neutral Communication } \\
\text { on sustainability }\end{array}$ & $\begin{array}{l}\text { Communication } \\
\text { for sustainability } \\
\text { (CfS) }\end{array}$ \\
\hline $\begin{array}{l}\text { Communication of } \\
\text { sustainability (CoS) }\end{array}$ & $\begin{array}{l}\text { Greenwashing in } \\
\text { sustainability } \\
\text { reporting }\end{array}$ & $\begin{array}{l}\text { Scientific communication } \\
\text { of "facts" ("public } \\
\text { understanding of science" } \\
\text { model) }\end{array}$ & $\begin{array}{l}\text { Educating students or } \\
\text { the public }\end{array}$ \\
\hline \multirow[t]{2}{*}{$\begin{array}{c}\text { Communication } \\
\text { about sustainability } \\
\text { (CaS) }\end{array}$} & $\begin{array}{l}\text { Discourses oriented to } \\
\text { impede genuine } \\
\text { sustainable } \\
\text { development }\end{array}$ & $\begin{array}{l}\text { Scientific deliberation } \\
\text { about sustainability- } \\
\text { related phenomena }\end{array}$ & $\begin{array}{l}\text { Participatory dialogues } \\
\text { in Local Agenda } 21 \\
\text { groups }\end{array}$ \\
\hline & defensive $>>>>>>$ & $>>>>>>>>>>>>$ & $>>>>>$ transformative \\
\hline
\end{tabular}

\subsection{Two Plus One: Different Perspectives on Sustainability Communication}

Within sustainability communication, we propose that two distinct perspectives can be taken: communication about sustainability $(\mathrm{CaS})$ and communication of sustainability $(\mathrm{CoS})$ [2,10]. Both differ in at least three aspects: the direction/mode of information flow, the function of communication, and the measures of effectiveness or quality of communication.

\subsection{Communication about Sustainability}

Communication about sustainability $(\mathrm{CaS})$ refers to processes in which information, interpretations, and opinions regarding sustainability issues are exchanged and debated. Issues are transformed and framed in horizontal communication that can take place on many different levels, ranging from interpersonal face-to-face interaction up to the mediated level of mass communication [13]. CaS constitutes our perception of sustainability issues as it serves important functions of framing issues and structuring facts, arguments, and claims by creating a common understanding of the issue at stake, of the goals that should be pursued, and of who needs to take action. Such processes are not necessarily harmonious and inclusive, but instead can be seen as "controversially structured fields of symbolic 
interaction in which a variety of actors struggle to establish their respective interpretation of problems, their causes and remedies" [14].

How might the effectiveness or quality of CaS be assessed? One indicator is the amount of attention that an issue receives from the mass media $[10,15]$. A second, procedural indicator refers to who has access to the discourse and influences the framing processes. Effectiveness then refers to structural conditions and the design of communication processes [16]. A third aspect concerns the (potential for) communication exchange between spheres, or subsystems, of communication [17]. An indicator of communication effectiveness would measure the extent to which the discourse in one subsystem (e.g., science) is compatible with discourses in other subsystems (e.g., the political system), and how likely it is to transfer important aspects from one subsystem to another so that, eventually, action toward sustainable development can be taken [18].

\subsection{Communication of Sustainability}

Communication of sustainability $(\mathrm{CoS})$, by contrast, is instrumental or managerial. It focuses on the primarily mono-directional, sender-receiver flow of communication, where the sender pursues a certain objective of communication [10]. Scientists, NGOs, educators, companies, and journalists seek to gain the attention of decision makers or the broader public in order to provide information about sustainability-related phenomena. As the demands of society for sustainable action grow, actors may see the need for $\mathrm{CoS}$ as a measure to defend or legitimize their behavior. Corporate sustainability reporting is one example of this type of communication.

Specific functions of $\mathrm{CoS}$ are to inform and educate individuals, and to achieve some type and level of social engagement and action [9]. In this respect, it takes an elitist stance, making a central distinction between experts and laypersons in respect to their sustainability-related knowledge and capacities [19]. Scientists in particular "have long held and will continue to hold a privileged position as knowledge holders, messengers, and interpreters of climate change" [9].

Since $\mathrm{CoS}$ has clear intentions about its desired effects, it lends itself to be assessed in terms of its effectiveness. Have the recipients been reached? Have they understood the message? Have they, perhaps, changed their values and behavior? Again referring to science, this mode of communication, in which "experts" educate "lay" people, is increasingly being criticized [19]. Recently, serious failures in communication regarding climate change have stunned public debate. Take for example, the IPCC's erroneous scenario of Himalayan glaciers melting by 2035, which IPCC officials continued to uphold under doubtful circumstances. This contributed to declining public confidence in climate scientists [20]. Not only is the privileged position of science eroding; increasingly, the dominant quest for behavioral change at the individual level (which has only had very limited success) is questioned in favor of dialogue and discourse [4]. Thus, CoS approaches the sphere of communication about sustainability.

\subsection{Communication for Sustainability}

While the distinction between $\mathrm{CaS}$ and $\mathrm{CoS}$ refers to the direction and the initiators of information flows, the concept of communication for sustainability (CfS) shifts emphasis to the normative aspect of sustainable development. In this sense, communication is not just about providing sustainability-related 
information and raising awareness for sustainability issues. Its objective is to facilitate societal transformation towards the normative goals of sustainable development. In terms of direction and senders, CfS may share elements of $\mathrm{CoS}$ and $\mathrm{CaS}$, including the knowledge generation, (social) learning [4], and collaboratively developing solutions for sustainability problems. The effectiveness of CfS relates to its impact in terms of measurable action towards sustainable development.

As Table 2 illustrates, CfS has counterparts in that sustainability-related communication may in fact (be intended to) neglect or even obstruct sustainable development. As hardly anyone is openly "against" sustainability, this is typically done by symbolically subscribing to sustainability while pursuing hidden non-sustainable agendas.

Although the boundaries between these different types of communication are somewhat blurred, they could provide a useful analytical lens when looking at the numerous communication processes to be found in the context of sustainable development.

\section{Sustainability-Related Communication in Societal Subsystems}

For the purpose of taking stock of sustainability-related communication across society, we were inspired by the theory of functional communication systems put forward by Luhmann [21]. Drawing on the latter, Weingart, Engels and Pansegrau [17] have shown for the field of climate change communication how different spheres (subsystems) of society operate according to specific "logics" to determine how sustainability issues are framed and processed. We should note that we do not follow Luhmann's systems approach exactly, in that we do acknowledge the role of agency in societal communication. In total, we have identified six subsystems, namely civil society, education, mass media, science, politics, and economy. While this choice should not imply a comprehensive selection, it represents in our view the most relevant and dynamic segments of society in relation to sustainable development. To analyze these, we explore how the categories of communication about, of and for sustainability (CaS, CoS, CfS) are reflected in the subsystem-specific discourses on sustainability communication. The aim of this chapter is not to provide a detailed review of the complex bodies of literature pertaining to each subsystem; instead, the focus is on capturing broader tendencies that will have to be further examined in the future, and to illustrate these tendencies by giving examples for the types of communication. To allow for consistency, our analysis refers mostly to the situation in Germany.

\subsection{Civil Society}

Civil society constitutes a societal subsystem distinct from the economic and the political subsystems as well as from the sphere of private life. In civil society, voluntary institutions are formed in order to pursue matters of public concern [22]. In the field of sustainable development, these institutions may be broadly referred to as the environmental movement [23]. Although there is a wide variety of actors concerning the degree of professionalization, types of activities, identities, and discourse frames, it may be safe to say that most actors within the environmental movement share a normative orientation towards changing potentially harmful human action in order to protect nature [24]. Therefore, most communication activities within this subsystem could in some way be classified as CfS. Next to this, forms of $\mathrm{CaS}$ are found that facilitate a common understanding of what constitutes environmental problems as well as sustainable solutions. Reaching beyond the immediate subsystem of civil society, 
such processes extend to the "green public sphere", which encompasses face to face interaction as well as mediated communication. $\mathrm{CoS}$, on the other hand, serves to draw public attention to matters concerned with sustainability. Since civil society actors typically lack significant political power or abundant financial resources, they rely on public attention to gather support for their causes. Consequently, they strive to enhance their communication activities, for example by adapting them towards mass media logic. Furthermore, civil society actors are increasingly involved in new forms of sustainability governance in which they seek to develop solutions for sustainability problems [25].

As participation in collaborative governance gains importance, questions of legitimacy and competence on behalf of civil society actors arise (ibid). From the perspective of civil society actors, cooperation and compromise might bear the risk of co-optation and loss of credibility towards their constituencies. Here, CaS might play a crucial role in democratizing communication and thus legitimizing positions of professional civil society representatives.

\subsection{Education}

Key sustainability concerns such as peace, environmental protection, or development cooperation have been advocated by different educational camps. Three different traditions can be distinguished, reflecting the overall distinction between different perspectives on sustainability communication outlined above: a facts-based (communication of sustainability), a pluralistic and deliberative (education about sustainability) and a more transformative (education for sustainability) tradition in approaching seminal societal concerns. Since the Rio summit in 1992, the notion of education for sustainable development (ESD) has received remarkable political support on an international level, cumulating in the launch of a United Nation's world decade on ESD (2005-2014). ESD is commonly viewed as an integrative framework that has the potential to forge alliances between different adjectival educations. In the scholarly and policy debate, ESD is viewed using competency-based emancipatory approaches over behavioral-based instrumental approaches and to thus reflect principles of communication about sustainability.

The implementation of ESD in different national educational systems is characterized by a great diversity of approaches and is progressing rather slowly [26]. In the European school sector, a number of governments have sponsored programs to pilot the implementation of ESD. While many of these programs report overall positive results [27], comparatively short funding periods, lack of long-term commitment, and of structural implementation impede the consolidation and broader dissemination of ESD in the school sector. The vocational sector in Europe has responded to the debate about sustainable development by incorporating sustainability issues into occupational profiles and curricula [28]. However, empirical findings show that the competence-approach proposed by and favored in the scholarly discussion has not yet translated into practice on a full scale, and that ESD practice is often reflecting principles of communication of rather than about sustainability [29].

The implementation of ESD in the higher education sector has been significantly pioneered by a number of dedicated universities that have organized themselves into informal networks such as the COPERNICUS Alliance or the ULSF (University Leaders for a Sustainable Future). While a number of new study programs addressing sustainability issues have been established, ESD is still rather poorly implemented in teacher education, despite a number of prominent initiatives [30]. An emerging 
theme in the higher education sector is that universities increasingly identify not only their curricula, but also their campuses, and their connections to the community outside the university boundaries as contexts for learning and enacting ESD [31].

Overall, ESD as a cross-curricular and interdisciplinary endeavor often struggles due to a lack of a solid integration in policy frameworks, curricula and syllabi. Given the abundance of political declarations and the absence of binding legal resolutions, a major impetus for the implementation of ESD so far comes from bottom-up initiatives, non-governmental networks, and committed groups of individuals and organizations [23].

\subsection{Mass Media}

During the past 20 years, mass media have been increasingly playing a significant role in bringing forward and establishing the concept of sustainability into the societal discourse. The media constitute a societal subsystem with cross-cutting character, providing strong interlinkages to all other subsystems. The media function as an observer of society, picking up dynamics within one subsystem, and delivering them into other societal spheres. Ideally, the media constitutes a public sphere that not only represents all relevant voices within society, but also offers a venue for discourse about issues. However, it would fall short to view the media as neutral observers, which merely transfer information from one subsystem to another. Such a perspective on media's societal function would ignore the specific set of logic within this subsystem, which determines modes of content selection and production (e.g., agenda setting, framing).

It is partly due to this set of logic that the complex and ambivalent concept of sustainable development has been less readily taken up by the mass media than more concrete issues, such as climate change, which have been receiving an enormous amount of media attention [10]. The mass media mainly focus on $\mathrm{CoS}$ in a sense that journalists report on topics such as scientific findings or political summits. Communication typically follows a mono-directional "one-to-many" mode [32], with little access to feedback loops that could possibly initiate discourse in the sense of CaS. However, certain interactive TV-formats or the publication of letters to the editor do present opportunities for CaS. As the internet (especially new social media formats) continues to gain popularity, mass media outlets are increasingly experimenting with more interactive forms of communication with even further potential for CaS. German public broadcasting has an educational mandate to inform and educate the public; thus public broadcasting has committed itself to communicate mainly in favor of sustainability, in line with the country's political agenda. In connection with media formats that propose a change for the rethinking of behavior, it is possible to consider this type of communication mode as CfS. Ultimately, discursive CaS supported by media communication has the potential to play a much more central role in entrenching a fundamental societal transformation process towards sustainability.

\subsection{Science}

The growing societal attention towards sustainable development is reflected by an increased resonance within the scientific subsystem. Science has made many disciplinary contributions to sustainable development (e.g., climate change research, environmental chemistry, sustainability economics). With regard to $\mathrm{CoS}$, information concerned with scientific results of sustainability issues 
is transferred to the public or other subsystems, e.g., politics. In particular, the results of climate change research have been disseminated by mass media and have been discussed in the general public [18]. However, the assumed dissemination of scientific knowledge in public space as a linear communication process has been criticized [5]. With regard to $\mathrm{CaS}$, science contributes to the production of an intersubjective understanding of sustainability by developing theories and concepts of sustainability. The scientific discourse on weak vs. strong sustainability, and the relevance of different dimensions of sustainability or constitutive elements of sustainable development may be considered in this context.

Ultimately, transdisciplinary sustainability science has become increasingly important. This emerging science represents an attempt to analyze the complex interplay of the environment and society, to offer new insights into existing problems, and develop new forms of knowledge [33,34]. With this development, the importance of $\mathrm{CaS}$, and in particular, of CfS in the scientific subsystem increases. Transdisciplinary sustainability science promotes sustainable development through science-practice cooperation in projects dealing with real-world sustainability problems [35]. Sustainability science not only generates systems knowledge (understanding the issue), but also target knowledge (determining corridors for decision making), and transformation knowledge (ways and means of implementing decisions) [36]. The growing importance of the scientific sustainability discourse, and the recognition of sustainability science as an independent research program also result in an increasing relevance of sustainability communication in the scientific subsystem. However, "sustainability science is not yet an autonomous field or discipline, but rather a vibrant arena [...]. Its scope of core questions, criteria for quality control, and membership are consequently in substantial flux and may be expected to remain so for some time" [37].

\subsection{Politics}

Dealing with sustainability in politics means to communicate about content, chances, opportunities, possible desired outcomes and ways to achieve them in producing collectively binding decisions. Different aspects of polity, policy, and politics are involved: institutions, goals, tasks of politics, and processes of opinion and decision making. The political subsystem shall be broadly understood as everything that "concerns the state (...) and the management of public affairs" [38]. In times of dispersed political power this broad conception makes it possible to include a wide range of actors (e.g., states, transnational corporations, consumers, NGOs, media, or the general public) [39]. More narrowly, we focus on political parties, members of administration, and government officials.

Communication processes in the political sphere involve advocacy of one's own prerogative of interpretation, trying to win people over, or to make them familiar with the political will of the respective political organization (communication of sustainability). Arenas are e.g., the media, or the Parliament. Depending on political priorities, the direction can be communication for, or communication against, sustainability. The communication may be neutral when its purpose is only to inform. Communication of, and with regard to, bureaucracy is typically more issue-related and can be attributed to these modes too.

When explaining politics of departments, it may also appear as CaS. At the same time, governments and their bureaucracies are involved in initializing $\mathrm{CaS}$ (i.e., the deliberative process of designing 
sustainability strategies). The German Sustainability Progress Report was created with the participation of stakeholders such as citizens, civil society actors, and/or academics. Other forms of political and state-offered sustainability communication are face-to-face forums (e.g., round table discussions) or media-mediated ones (online forums). The media have a vital role in political communication. This applies to the propagation of content and political ideas (also of political lobby groups), but also plays a role at the interfaces between different spheres of politics, administration, science, or economy.

In sum: Sustainability communication in the sphere of politics includes all displayed modes; the particular use depends on the respective configuration of the situation and the balance of power.

\subsection{Business/Economy}

In a corporate context, sustainability issues are typically communicated under the label corporate social responsibility (CSR). CSR is an increasingly important component of corporate communication [40]. According to Podnar, CSR communication is 'a process of anticipating stakeholders' expectations, articulation of CSR policy and managing of different organization communication tools designed to provide true and transparent information" [41]. Recognition of stakeholders and dialogue orientation are key elements of CSR communication. It is closely linked to trust and credibility, and an important aspect of image creation, reputation management, as well as issues management. Thus, CSR communication is also a crucial part of corporate "communication management" which aims at managing communication situations and communication relationships. For this reason, CSR communication is sometimes seen (as a part of public relations) as a form of "greenwashing" if the communication of CSR engagement is not linked to genuine sustainable behavior in the core business. On the other hand, public relations could be seen as part of CSR communication, arguing that corporate communication has to change from communication management to a broader responsibility management.

Communication in this subsystem is mainly $\mathrm{CoS}$ which is characterized by a sender-receiver relationship and a transfer of information towards an objective. The reputation of a corporation is increasingly influenced by, and dependent upon the positive and effective sustainability communication. Thus, corporations want stakeholders to be informed about sustainable behavior in order to improve the corporate reputation. They are communicating their sustainability engagement via tools such as printed reports and the internet. The internet is a medium that can assist, extend or replace printed corporate sustainability reporting [42]. Moreover, a more dialogical communication method such as stakeholder dialogues (e.g., through participation in workshops and conferences on CSR), can be seen as $\mathrm{CaS}$ if companies act in a communicative manner in the sense of the Habermasian discourse ethics [43]. Sustainability reporting is currently mainly done only by large corporations and of increasing importance for their corporate publications. Ideally, such corporate $\mathrm{CoS}$ and $\mathrm{CaS}$ can also be used as CfS, which will lead the corporations to reflect further on their own sustainable development.

\section{Discussion}

The subsystem analysis of different sustainability-related modes of communication (see Table 3 for an overview and typical examples) has revealed a diverse picture of communication activities. Furthermore, three issues seem to emerge from this exploration. First, along with a general stronger 
societal awareness of sustainability, communication in the subsystems appears to be shifting from "neutral" discourses (e.g., in science or business) to a more normative orientation as embodied in CfS.

Table 3. Overview of societal subsystems and their sustainability-related communication modes.

\begin{tabular}{|c|c|c|c|c|}
\hline & $\begin{array}{l}\text { Communication about } \\
\text { sustainability (CaS) }\end{array}$ & $\begin{array}{l}\text { Communication of } \\
\text { sustainability (CoS) }\end{array}$ & $\begin{array}{l}\text { Communication for } \\
\text { sustainability (CfS) }\end{array}$ & $\begin{array}{l}\text { Relevance of } \\
\text { sustainability-related } \\
\text { communication to } \\
\text { achieving sustainable } \\
\text { development }\end{array}$ \\
\hline $\begin{array}{l}\text { Civil } \\
\text { Society }\end{array}$ & $\begin{array}{l}\text { Discourses on SD in } \\
\text { (alternative) media, } \\
\text { assemblies, social } \\
\text { networks }\end{array}$ & $\begin{array}{l}\text { awareness and information } \\
\text { campaigns, mass media } \\
\text { marketing }\end{array}$ & $\begin{array}{l}\text { political pressure, participation } \\
\text { and cooperation in SD } \\
\text { governance, self-organized } \\
\text { cooperatives }\end{array}$ & $\begin{array}{l}\text { introducing bottom-up } \\
\text { concerns, ideas and } \\
\text { solutions into society }\end{array}$ \\
\hline Education & $\begin{array}{l}\text { Engagement with different } \\
\text { interpretations of SD }\end{array}$ & $\begin{array}{l}\text { Transfer of facts in traditional } \\
\text { classroom settings }\end{array}$ & $\begin{array}{l}\text { Competence-oriented } \\
\text { approaches that encourage } \\
\text { students to take action in their } \\
\text { local surroundings }\end{array}$ & $\begin{array}{l}\text { Enabling individuals to play } \\
\text { an active role in SD }\end{array}$ \\
\hline $\begin{array}{l}\text { Mass } \\
\text { media }\end{array}$ & $\begin{array}{l}\text { Talk shows, letters to the } \\
\text { editor, commentary, } \\
\text { online-discussions }\end{array}$ & $\begin{array}{l}\text { environmental journalism, } \\
\text { edutainment, documentaries }\end{array}$ & $\begin{array}{l}\text { Media initiatives and special } \\
\text { issues with sustainability focus }\end{array}$ & $\begin{array}{l}\text { Contribution to societal } \\
\text { awareness of sustainability } \\
\text { problems }\end{array}$ \\
\hline Science & $\begin{array}{l}\text { Scientific discourse on } \\
\text { theories and concepts of } \\
\text { SD }\end{array}$ & $\begin{array}{l}\text { Transfer of information on } \\
\text { scientific results concerning } \\
\text { sustainability issues (science } \\
\text { communication, public } \\
\text { understanding of science) }\end{array}$ & $\begin{array}{l}\text { Transdisciplinary sustainability } \\
\text { science (normative approach, } \\
\text { promoting SD) }\end{array}$ & $\begin{array}{l}\text { Contributions to the } \\
\text { solution of sustainability } \\
\text { problems and awareness of } \\
\text { society }\end{array}$ \\
\hline Politics & $\begin{array}{l}\text { Raising public awareness } \\
\text { and initializing } \\
\text { communication: } \\
\text { Governments and their } \\
\text { bureaucracies }\end{array}$ & $\begin{array}{l}\text { Making people familiar with } \\
\text { the political will of: } \\
\text { Parties, governments, } \\
\text { bureaucracies }\end{array}$ & $\begin{array}{l}\text { Displaying own solutions. } \\
\text { Parties, NGOs, Governments, } \\
\text { bureaucracies }\end{array}$ & $\begin{array}{l}\text { Contribution to raising } \\
\text { public awareness of } \\
\text { sustainability; highlighting } \\
\text { different perceptions of SD } \\
\text { (interests) }\end{array}$ \\
\hline $\begin{array}{l}\text { Economy/ } \\
\text { industry }\end{array}$ & $\begin{array}{l}\text { Workshops and } \\
\text { conferences on SD and } \\
\text { CSR }\end{array}$ & $\begin{array}{l}\text { Transfer of information on } \\
\text { sustainable behavior in order to } \\
\text { improve reputation }\end{array}$ & $\begin{array}{l}\text { Communication that goes } \\
\text { beyond reputational aspects; } \\
\text { effects (i.e., of stakeholder } \\
\text { dialogues) on corporate } \\
\text { behavior and management }\end{array}$ & $\begin{array}{l}\text { Integrating sustainability } \\
\text { related concerns of } \\
\text { stakeholders }\end{array}$ \\
\hline
\end{tabular}

Second, CoS has proliferated within all subsystems. Having started as an elite discourse, sustainability-related issues are routinely communicated from elites (NGOs, teachers, scientists) to their respective basis or constituency (the broader public, students). However, a gradual shift can be observed from $\mathrm{CoS}$ towards $\mathrm{CaS}$, as witnessed by the introduction of competency-based approaches to education for sustainable development, transdisciplinary sustainability science, collaborative forms of sustainability governance, and some forms of corporate social responsibility. This rising importance of $\mathrm{CaS}$ may be an indication of an increasingly participatory discourse, moving from elite to a more egalitarian approach.

Third, each subsystem exhibits distinct internal modes of operation that lead to subsystem-specific forms of communication regarding sustainability, reflecting the functional approach put forward by Luhmann and others. This is consistent with the findings by Weingart et al. that "communication is essentially different in each of the distinct spheres [of mass media, politics, and science], and that 
disturbances of communication among these spheres are hence the rule rather than the exception" [17]. These disturbances, which have been leading to frustration particularly among the "misunderstood senders" of sustainability-related communication (e.g., scientists whose ideas are not taken up "correctly" by the media and are not "implemented" by policy) typically relate to the CoS mode.

Moving beyond the approach by Weingart et al. [17], our analysis suggests that next to the (arguably problematic) $\mathrm{CoS}$ mode of communicating across subsystem boundaries, the CaS mode could prove more fruitful for tackling sustainability problems. Along these lines, we consider three pivotal CaS-based linkages that form clustered discourses each involving multiple subsystems. Not surprisingly, these "clusters" turn out to reflect three key features of the broader societal discourse on sustainability: transdisciplinarity, deliberation, and governance. They serve as examples of how subsystems may be opened up to one another via CaS (see Table 4).

Table 4. Achieving sustainability through opening up of established communication subsystems.

\begin{tabular}{llll}
\hline $\begin{array}{l}\text { Label of } \\
\text { discourse }\end{array}$ & $\begin{array}{l}\text { Core } \\
\text { subsystem }\end{array}$ & $\begin{array}{l}\text { "Opening up" towards } \\
\text { other subsystems }\end{array}$ & Function \\
\hline $\begin{array}{l}\text { Trans- } \\
\text { disciplinarity }\end{array}$ & Science & $\begin{array}{l}\text { Politics, civil society, } \\
\text { private business, education }\end{array}$ & $\begin{array}{l}\text { Meet the uncertainty challenge by } \\
\text { producing socially robust knowledge }\end{array}$ \\
\hline $\begin{array}{l}\text { Societal } \\
\text { deliberation }\end{array}$ & Mass media & Civil society, politics & $\begin{array}{l}\text { Meet the ambivalence challenge by } \\
\text { producing shared visions on } \\
\text { sustainability }\end{array}$ \\
\hline Governance & Politics & $\begin{array}{l}\text { Civil society, private } \\
\text { business }\end{array}$ & $\begin{array}{l}\text { Meet the implementation challenge by } \\
\text { producing better accepted decisions }\end{array}$ \\
\hline
\end{tabular}

These constellations are neither surprising nor original. Each has been extensively discussed and propagated in the context of sustainable development. However, our approach offers a coherent view and a common language to perceive transdisciplinarity, societal deliberation, and governance as

- phenomena of communication and

- an opening up of societal communication subsystems.

Transdisciplinarity, also referred to as post-normal [12] or mode 2 science [44], is expressed by an opening up of science to other subsystems, mostly in a CaS manner. In order to cope with increasing complexity and uncertainty of mounting issues of sustainability, transdisciplinary science engages with actors from civil society, politics, private business or education. Non-science actors are not only receivers of information (as would be in a $\mathrm{CoS}$ mode), but collaborate in framing research questions and producing new and more relevant kinds of contextualized, "socially robust" knowledge [44,45]. The emerging sustainability science is a paradigmatic example of transdisciplinary science in CfS mode.

Societal Deliberation: As Habermas [46] has noted, societal debates in modern society are predominantly mediated by the mass media, thus constituting an elite discourse. We have seen, however, that the mass media constitutes a communication system that operates according to its own logic, and that communication with other subsystems mostly occurs in CoS mode. In order to cope with the ambivalence challenge of sustainability, broader public (or rather societal) deliberation is advocated that transgresses the mass-media based discourse and that operates in CaS mode. Examples include mostly technology discourses (GMO, nano-technology, and nuclear energy), which employ "alternative" forms of discourse such as large-scale public consultations. Recently, "web 2.0" features 
have also been providing potential for more participatory discourses, thus opening up the media subsystem to some extent [47].

Governance, as opposed to government, refers to an opening up of the political sub-system to other subsystems, notably civil society and private business. New forms of participatory, collaborative, and network-oriented decision-making are introduced into public policy and administration, again drawing on $\mathrm{CaS}$ as the dominant mode of communication over CoS. Face-to-face deliberative and other forms of communication with non-state actors are sought to enhance the information basis, acceptability, and implementation of decisions, ultimately leading to more sustainable management [48].

It should be noted, however, that these mechanisms of "opening up" have not remained without criticism. With regard to the notion of transdisciplinarity, the "robustness" of "socially robust knowledge" has been brought into question [49].Civic participation in administrative decision-making has been judged ineffective because of clashing rationales of the respective societal subsystems [50]. Empirical research will have to specify the conditions under which an "opening up" will be conducive (or counterproductive) to sustainability.

\section{Conclusions}

We have developed a typology that distinguishes different forms of sustainability communication: essentially communication about, of, and for sustainability (CaS, CoS and CfS). Applying this typology to current developments in six communication subsystems of society, we found the typology to be useful for comparative analysis. The introduction of three types of communication allows one to analytically distinguish between the communication processes (how) and the material interests and outcomes of these processes (what).

Drawing mostly on examples from Germany, the analysis reveals a general tendency towards CfS, reflecting the normative principles inherent to sustainable development. Secondly, we observe that while an elite-based CoS mode is generally well established, there is an overall shift towards a more horizontal, participatory CaS mode within most subsystems. Third, we find that while generally communication subsystems tend to be operationally closed (as maintained by Luhmann and others), a variety of communication interlinkages exist. Of key interest for addressing mounting sustainability challenges is the "opening up" of particular subsystems. Opening up science, mass media and politics towards other subsystems in $\mathrm{CaS}$ mode leads to transdisciplinarity, societal deliberation and governance, which are all generally considered to be vital to successful transition to sustainability. Each of these meets one of the core challenges to sustainability outlined in the introduction: the complexity/uncertainty challenge, the challenge of ambivalence, and the challenge of implementation. Our framework for analyzing sustainability-related communication has thus provided a consistent (re-)formulation of those key concepts for achieving sustainability.

Much research remains to be done in order to more fully understand the specific operation of sustainability-related communication in societal subsystems or other entities. A rigorous empirical analysis of the subsystems will be crucial to test and further examine the communication types and tendencies that our exploration has identified. A promising pathway could be to pursue mixed method approaches, such as combining structural analysis of one or more subsystems (e.g., media logic, teaching, political processes) with discourse analysis and analysis of the dynamics of specific 
sustainability issues. We hope to inspire fellow researchers and practitioners to generate useful insights on how to study and improve communication that facilitates transitions to sustainability by applying this framework.

\section{Conflict of Interest}

The authors declare no conflict of interest.

\section{References}

1. Schneidewind, U.; Feindt, P.H.; Meister, H.-P.; Minsch, J.; Schulz, T.; Tscheulin, J. Institutionelle Reformen für eine Politik der Nachhaltigkeit: Vom Was zum Wie in der Nachhaltigkeitsdebatte (in German). GAIA 1997, 6, 182-196.

2. Godemann, J.; Michelsen, G. Sustainability Communication-An Introduction. In Sustainability Communication: Interdisciplinary Perspectives and Theoretical Foundation; Godemann, J., Michelsen, G., Eds.; Springer: Dordrecht, The Netherlands, New York, NY, USA, 2011; pp. 3-11.

3. Newig, J.; Voß, J.-P.; Monstadt, J. Governance for Sustainable Development: Coping with Ambivalence, Uncertainty and Distributed Power; Routledge: London, UK, 2008.

4. Barth, M. Social learning instead of educating each other. GAIA 2012, 21, 91-94.

5. Adomßent, M.; Godemann, J. Sustainability Communication: An Integrative Approach. In Sustainability Communication: Interdisciplinary Perspectives and Theoretical Foundation; Godemann, J., Michelsen, G., Eds.; Springer: Dordrecht, The Netherlands, New York, NY, USA, 2011; pp. 27-37.

6. Agyeman, J. Communicating “just Sustainability”. Environ. Commun. 2007, 1, 119-122.

7. Lindenfeld, L.A.; Hall, D.M.; McGreavy, B.; Silka, L.; Hart, D. Creating a Place for Environmental Communication Research in Sustainability Science. Environ. Commun. 2012, 6, 23-43.

8. Hendriks, C.M. Policy design without democracy? Making democratic sense of transition management. Policy Sci. 2009, 42, 341-368.

9. Moser, S.C. Communicating climate change: History, challenges, process and future directions. WIREs Clim. Chang. 2010, 1, 31-53.

10. Newig, J. Climate Change as an Element of Sustainability Communication. In Sustainability Communication: Interdisciplinary Perspectives and Theoretical Foundations; Godemann, J., Michelsen, G., Eds.; Springer: Dordrecht, The Netherlands, New York, NY, USA, 2011; pp. 119-128.

11. Bilharz, M.; Schmitt, K. Going big with big matters: The key points approach to sustainable consumption. GAIA 2011, 20, 232-235.

12. Funtowicz, S.O.; Ravetz, J.R. Science for the post-normal age. Futures 1993, 25, 739-755.

13. Neidhardt, F. The public as a communication system. Public Underst. Sci. 1993, 2, 339-350.

14. Brand, K.-W. Sociological Perspectives on Sustainability Communication. In Sustainability Communication: Interdisciplinary Perspectives and Theoretical Foundations; Godemann, J., Michelsen, G., Eds.; Springer: Dordrecht, The Netherlands, New York, NY, USA, 2011; pp. 55-68.

15. Bonfadelli, H. Environmental Sustainability as Challenge for Media and Journalism. In Environmental Sociology: European Perspectives and Interdisciplinary Challenges; Gross, M., Heinrichs, H., Eds.; Springer: Dordrecht, The Netherlands, New York, NY, USA, 2010; pp. 255-278. 
16. Rowe, G.; Frewer, L.J. A typology of public engagement mechanisms. Sci. Technol. Hum. Values 2005, 30, 251-290.

17. Weingart, P.; Engels, A.; Pansegrau, P. Risks of communication: Discourses on climate change in science, politics, and the mass media. Public Underst. Sci. 2000, 9, 261-283.

18. Egner, H. Surprising coincidence or successful scientific communication: How did climate change enter into the current public debate? Gaia-Ecol. Perspect. Sci. Soc. 2007, 16, 250-254.

19. Nerlich, B.; Koteyko, N.; Brown, B. Theory and language of climate change communication. WIREs Clim. Chang. 2010, 1, 97-110.

20. Leake, J.; Hastings, C. World Misled over Himalayan Glacier Meltdown. The Times, 17 January 2010.

21. Luhmann, N. Social Systems; Stanford University Press: Palo Alto, CA, USA, 1995.

22. Brulle, R.J. From Environmental Campaigns to Advancing the Public Dialog: Environmental Communication for Civic Engagement. Environ. Commun. 2010, 4, 82-98.

23. Brand, K.-W. Umweltbewegung (inkl. Tierschutz). In Die sozialen Bewegungen in Deutschland seit 1945 (in German); Roth, R., Rucht, D., Eds.; Campus-Verl.: Frankfurt/Main, Germany, 2008; pp. 219-244.

24. Torgerson, D. Farewell to the green movement? Political action and the green public sphere. Environ. Polit. 2000, 9, 1-19.

25. Weidner, H. Nachhaltigkeitskooperation: Vom Staatspessimismus zur Zivilgesellschaftseuphorie? In Zivilgesellschaft-National und Transnational (in German); Gosewinkel, D., Rucht, D., van den Daele, W., Kocka, J., Eds.; Edition Sigma: Berlin, Germany, 2004; pp. 383-410.

26. Wals, A.E.J. Review of Contexts and Structures for Education for Sustainable Development: Learning for a Sustainable World; UNESCO: Paris, France, 2009.

27. Hacking, E.B.; Scott, W.R.; Lee, E.A. Evidence of Impact on Sustainable Schools; UK Department for Children, Schools and Families: Nottingham, UK, 2010.

28. Viertel, E. Vocational education for sustainable development: An obligation for the European Training Foundation. Eur. J. Educ. 2010, 45, 217-235.

29. Rode, H. Motivation, Transfer und Gestaltungskompetenz: Ergebnisse der Abschlussevalution des BLK-Programms 21 1999-2004 (in German); Verein zur Förderung der Ökologie im Bildungsbereich: Berlin, Germany, 2005.

30. Sleurs, W. Competencies for ESD (Education for Sustainable Development) Teachers. A Framework to Integrate ESD in the Curriculum of Teacher Training Institutes; Curriculum Department, Ministry of Education and Formation, Ministry of the Flemish Community: Brüssel, Belgium, 2008.

31. Müller-Christ, G.; Sterling, S.; van Dam-Mieras, R.; Adomßent, M.; Fischer, D.; Rieckmann, M. The role of campus, curriculum, and community in higher education for sustainable development - a conference report. Available online: http:/www.sciencedirect.com/science/article/pii/ S0959652613001005 (accessed on 1 April 2013).

32. O’Neill, S.; Boykoff, M. The Role of New Media in Engaging the Public with Climate Change. In Engaging the Public with Climate Change; Whitmarsh, L., O’Neill, S., Lorenzoni, I., Eds.; Earthscan: London, UK, 2011. 
33. Swart, R.J.; Raskin, P.; Robinson, J. The problem of the future: Sustainability science and scenario analysis. Global Environ. Chang. 2004, 14, 137-146.

34. Kates, R.; Clark, W.C. Sustainability Science. Available online: http://papers.ssrn.com/sol3/ papers.cfm?abstract_id=257359 (accessed on 1 April 2013).

35. Schneidewind, U. Ein institutionelles Reformprogramm zur Förderung transdisziplinärer Nachhaltigkeitsforschung. GAIA 2010, 19, 122-128.

36. Daschkeit, A. Von der naturwissenschaftlichen Umweltforschung zur Nachhaltigkeitswissenschaft? GAIA-Ecol. Perspect. Sci. Soc. 2006, 15, 37-43.

37. Clark, W.C.; Dickson, N.M. Sustainability science: The emerging research program. Proc. Natl. Acad. Sci. USA 2003, 100, 8059-8061.

38. Heywood, A. Politics, 2nd ed.; Palgrave Macmillan: New York, NY, USA, 2002.

39. Hajer, M. Policy without polity? Policy analysis and the institutional void. Policy Sci. 2003, 36, 175-195.

40. Arvidsson, S. Communication of Corporate Social Responsibility: A Study of the Views of Management Teams in Large Companies. J. Bus. Ethics 2010, 96, 339-354.

41. Podnar, K. Guest Editorial: Communicating Corporate Social Responsibility. J. Mark. Commun. 2008, 14, 75-81.

42. Herzig, C.; Godemann, J. Internet-supported sustainability reporting: Developments in Germany. Manag. Res. Rev. 2010, 33, 1064-1082.

43. Burkart, R. Consensus-Oriented Public Relations (COPR) - A Conception for Planning and Evaluation of Public Relations. In Public Relations in Europe: A Nation-by-Nation Introduction to Public Relations Theory and Practice; Ruler, B.V., Vercic, D., Eds.; Mouton de Gruyter: Berlin, Germany, 2004; pp. 446-452.

44. Nowotny, H.; Scott, P.; Gibbons, M. Re-Thinking Science. Knowledge and the Public in an Age of Uncertainty; Polity Press: Oxford, UK, 2004.

45. Wiek, A. Challenges of Transdisciplinary Research as Interactive Knowledge Generation. GAIA 2007, 16, 52-57.

46. Habermas, J. The Structural Transformation of the Public Sphere: An Inquiry into a Category of Bourgeois Society; MIT Press: Cambridge, MA, USA, 1991; originally appeared in German 1962.

47. Thurman, N. Forums for citizen journalists? Adoption of user generated content initiatives by online news media. New Media Soc. 2008, 10, 139-157.

48. Newig, J.; Fritsch, O. Environmental Governance: Participatory, Multi-Level—and Effective? Environ. Policy Gov. 2009, 19, 197-214.

49. Weingart, P. How Robust Is "Socially Robust Knowledge"? In The Challenge of the Social and the Pressure of Practice. Science and Values Revisited; Carrier, M., Howard, D., Kourany, J.A., Eds.; University of Pittsburgh Press: Pittsburgh, PA, USA, 2008; pp. 131-145.

50. Bora, A.; Hausendorf, H. Participation and Beyond: Dynamics of Social Poitions in Participatory Discourse. Comp. Sociol. 2009, 8, 602-625.

(C) 2013 by the authors; licensee MDPI, Basel, Switzerland. This article is an open access article distributed under the terms and conditions of the Creative Commons Attribution license (http://creativecommons.org/licenses/by/3.0/). 